dealt with in a symposium session which covered aspects of general and hospital practice. A contribution to the latter session gave a more widespread picture of the subject and illustrated the remarkable expansion of knowledge achieved since the general discussion on penicillin at the 1946 Conference.

Other developments in the field of pharmaceutics included the successful use of infra-red radiation for drying a wide variety of products. Bacterial survival in systems of low moisture content was further reported upon, namely, the effects of increasing moisture content on heat resistance, viability and growth of $B$. subtilis spores. The determination of quality of surgical dressings had been further investigated, on this occasion being concerned with their water retention.

S. B. Challen

\section{FISHERIES RESEARCH UNIT OF THE UNIVERSITY OF HONG KONG}

THE need for a Fisheries Research Station in Hong Kong has long been realized; but the various plans for one which have been put forward from time to time have for various reasons been found impracticable. However, a satisfactory scheme was recently worked out by the University of Hong Kong in conjunction with the local Government, and a Fisheries Research Unit commenced work recently in the University's Department of Biology. The University has provided approximately a thousand square feet of laboratory accommodation for the Unit, and the director is reader in marine biology on the University's staff. The association between the Unit and the Department of Biology. resembles that existing between various agricultural research units which are attached to a number of universities in Great Britain, for example, the Bureau of Animal Population and the Department of Zoology in the Unjversity of Oxford.

The director, Mr. Alan Tubb, who was formerly director of fisheries in the Colony of North Borneo, will take up his duties in April next year ; meanwhile, Prof. D. Barker, professor of zoology and head of the Department of Biology in the University, is acting director. The director will be assisted by a chief scientific officer and three assistant scientific officers; so far, two assistants have been engaged. The rest of the staff establishment consists of a laboratory steward and attendants, and the skipper and crew of a research vessel at present under construction. The laboratory accommodation includes marine aquaria supplied with running sea-water, and a laboratory suitable for chemical and biological work. There is a considerable library of books and journals on fisheries research, and the Unit has access to the University's scientific library. Provision has been made for equipping the Unit's laboratory with the appropriate research facilities and apparatus. The cost of establishing the Unit is being met out of Colonial Development and Welfare funds, while recurrent expenditure is being met by the local Government; in each case the government contribution is by means of block grants made over to the University for its administration.

The research vessel is a 66-ft. diesel-powered otter trawler. The keel is now being laid and she should be in commission by the summer of 1953. She will be equipped with a laboratory, echo sounder, radio telephone and wireless telegraphy, bottom sampler, bathythermograph, and various other apparatus required for oceanographical work. The vessel will work in waters up to a hundred miles distant from Hong Kong, and the longest trips will be of from seven to ten days duration.

From the point of view of marine research, Hong Kong is very favourably situated, being at the extreme south-east corner of Asia almost at the junction of temperate and tropical waters and within easy reach of ocean and estuarine fishing grounds. The Fisheries Research Unit is the most easterly of a chain of Commonwealth fisheries research stations, and its researches and findings will not only be correlated with those of Ceylon, Malaya and India, but will also be of value to the Dominions of Canada and Australia and to other countries which border on the Pacific Ocean or the China Sea. It is expected that the research carried out by the Unit will lead to improvements of catch in the immediate neighbourhood of Hong Kong and will contribute substantially to general fisheries research in the IndoPacific region. Under the auspices of the Indo-Pacific Fisheries Council, the Unit will pool its results and collaborate with similar stations in the Philippines, North Borneo, French Indo-China and Malaya in research projects relating to the China Sea. Among other problems the Unit will aim at undertaking the following research: survey the existing fishing grounds around Hong Kong, map them, and determine their species population and production; survey the sea-bottom, salinity and plankton in local waters; study ocean currents and the effect of such currents and prevailing winds on the movement of fish, with the possibility of discovering new fishing grounds; determine the influence of the Pearl River on the fishing around Hong Kong; study factors influencing the yield of catch in the local fishing grounds with the view of forecasting production; investigate the movement and feeding habits of fish, and, wherever possible, locate spawning grounds, etc., with the aim of trying to initiate control ; make studies in relation to the extension and improvement of salt, brackish and freshwater fish-pond culture.

\section{UNESCO INSTITUTE FOR EDUCATION, HAMBURG}

$\mathrm{U}$

NESCO has recently sponsored an unusually interesting experiment in West Germany, on a smaller scale than those activities with which Unesco is popularly associated. The experiment consists of the establishment of three Institutes, each of which began work during 1952 . One is for Social Sciences, at Cologne ; one for Youth, at Munich ; and one for Education, in Hamburg.

These Institutes are remarkable in two respects. First, each has an international governing board consisting of seven non-German and six German members, the funds of which are derived not from the general Unesco budget but in response to an appeal by the Director-General to individual nations. Secondly, the Federal Republic of Germany has agreed to and encouraged the establishment within its own territory of institutes over which it has not a controlling majority, but which it is prepared to finance up to a minimum of twenty per cent of their budgets. Perhaps equally noteworthy is the fact that among those nations which have contributed small 